\title{
Perilaku Memilih Masyarakat Pasca Runtuhnya Dinasti Kekuasaan di Kutai Kartanegara
}

\section{Fadli Afriandi ${ }^{1}$}

\begin{abstract}
Abstrak
Tulisan ini menampik klaim kajian perilaku memilih masyarakat yang telah menuju pola rasional, baik di level nasional maupun lokal. Tulisan ini mengajukan tesis bahwa runtuhnya dinasti kekuasaan menyebabkan perilaku memilih masyarakat kembali ke pola primordial yang awalnya menunjukkan pola rasional. Dinasti kekuasaan ini berada di tingkat lokal, tepatnya dinasti Syaukani-Rita di Kutai Kartanegara. Fokus penelitian ini melihat pada dominasi Rita Widyasari yang unggul di beberapa survei dalam bursa calon gubernur provinsi Kalimantan Timur namun gagal ikut di kontestasi tersebut karena tersandung masalah hukum. Penelitian ini menggunakan metode kualitatif dan teknik pengumpulan data melalui wawancara. Temuan dalam penelitian ini adalah perilaku memilih masyarakat menunjukkan pola primordial. Pola primordial masyarakat tersebut berdasarkan pada basis identitas suku dan agama yang terbagi ke dalam tiga wilayah (hulu, hilir/tengah, dan pesisir). Daerah hulu yang mayoritas suku Dayak cenderung memilih Syaharie Jaang, daerah hilir didominasi suku Kutai memilih Isran Noor, dan di wilayah pesisir yang didominasi suku Bugis lebih memilih Andi Sofyan Hasdam. Sedangkan berdasarkan agama, masyarakat memilih karena figur Hadi Mulyadi yang merupakan pasangan Isran Noor karena kelihatan lebih agamais.
\end{abstract}

Kata Kunci: Identitas; Kewilayahan; Pilkada; Perilaku Pemilih

1 Fadli Afriandi adalah alumnus Program Magister pada Departemen Politik dan Pemerintahan, Universitas Gadjah Mada dengan minat kajian Politik Nasional. 


\section{Pendahuluan}

Kehidupan di negara demokrasi seperti yang dianut oleh Indonesia, utamanya pemilihan pemimpin, baik di level nasional maupun daerah, merupakan hal yang mutlak dilakukan dan menjadi syarat berjalannya demokrasi. Keadaan tersebut menjadi sebuah pesta dalam negara yang menganut paham demokrasi. Rakyat sebagai aktor utama dalam demokrasi menjadi begitu banyak diperhatikan terutama menjelang kontestasi hingga pelaksanaan pemilihan umum, yang meliputi segala level pemilihan. Tulisan ini berusaha mengungkap perilaku memilih masyarakat terhadap kontestasi pemilihan kepala daerah. Fokus penelitian ini berada di kabupaten Kutai Kartanegara, yang merupakan salah satu kabupaten di provinsi Kalimantan Timur. Tahun 2018 merupakan tahun politik di provinsi tersebut, di sana diadakan pemilihan gubernur dan wakil gubernur.

Tulisan ini menjadi penting diteliti karena untuk membuktikan bahwasanya kajian perilaku memilih masyarakat di Indonesia yang selama ini diklaim telah beranjak dari pola pemilih yang dulunya masih primordial menuju rasional, baik di level nasional maupun lokal (Agustino \& Yusoff, 2009). Dalam tulisan ini, klaim tersebut tidak sepenuhnya terjadi. Tulisan ini melihat bagaimana perilaku memilih masyarakat yang kembali menunjukkan pola primordial. Hal ini dapat dilihat dalam perilaku memilih masyarakat pasca runtuhnya dinasti kekuasaan yang telah berkuasa 12 tahun di Kutai Kartanegara. Dinasti yang dimaksud yaitu kekuasaan Syaukani Hasan Rais dan Rita Widyasari yang merupakan bupati Kutai Kartanegara terpilih berturutturut. Syaukani memimpin Kutai Kartanegara dua periode: 1999-2004 dan 2005-2006, sedangkan Rita memimpin di tahun 2010-2015 dan 2016-2017. Syaukani dan Rita memiliki hubungan darah, Syaukani adalah ayah dari Rita. 
Kontestasi pemilihan gubernur dan wakil gubernur di Kalimantan Timur sejak tahun 2017 telah terlihat calon yang akan maju. Salah satunya adalah Rita Widyasari yang merupakan politisi dari partai Golongan Karya (Golkar) yang menjadi bupati perempuan pertama di Kalimantan Timur. Awalnya, kehadiran Rita menjadi bupati merupakan sebuah bentuk transformasi patronase yang kemudian bereproduksi menjadi oligarki (Santoso, Bayo \& Samadhi, 2018). Selain itu, Rita juga lahir akibat adanya kiprah tim 11 yang merupakan produk dari Syaukani. Di tahun 2017, Rita gencar melakukan sosialisasi setelah deklarasi yang dilakukan oleh partai Golkar yang mengusung Rita sebagai calon gubernur Kalimantan Timur. Di Kutai Kartanegara sendiri, masyarakat meyakini bahwa kehadiran Rita dalam pilgub akan sangat mudah meraup suara untuk memenangkan pilgub di Kalimantan Timur. Keyakinan masyarakat ini juga didukung oleh hasil dari beberapa lembaga survei yang melihat bahwa kehadiran Rita dalam bursa pemilihan gubernur tersebut mendominasi atas calon lainnya (Tribunnews, 2018).

Rita merupakan bupati Kutai Kartanegara dua periode yang dimulai di tahun 2010. Dalam pemilihan bupati Kutai Kartanegara tahun 2015, Rita kembali diumumkan keluar sebagai pemenang. Rita menang telak atas lawan-lawannya yang berhasil mengumpulkan 261.612 suara atau 89,38\% (KPU, 2015). Namun di bulan September 2017, Rita tersandung kasus yang membuat dirinya berhubungan dengan KPK dan berakibat terhentinya dia maju dalam memperebutkan kursi gubernur Kalimantan Timur.

Teknik pengumpulan data dalam penelitian ini adalah melalui wawancara. Wawancara dilakukan dengan masyarakat yang dikelompokkan ke dalam tiga wilayah, yaitu daerah hulu (pedalaman), hilir (tengah), dan pesisir. Wawancara dilakukan dengan tujuan untuk mengetahui putusan pilihan masyarakat terhadap calon gubernur dan wakil gubernur serta menyandingkan dengan Rita sebagai tokoh 
Kutai Kartanegara yang awalnya akan mengikuti pemilihan gubernur tersebut.

\section{Alasan Orang Memilih}

Kajian terhadap perilaku memilih di Indonesia telah banyak dilakukan oleh para ilmuan politik (Geertz, 1960; Gaffar, 1992; Ananta \& Suyadinata, 2004; Yustiningrum dan Ichwanuddin, 2015; Baswedan, 2004; Mujani, Liddle, \& Ambardi, 2012; dan Agustino \& Yusoff, 2009). Kajian tersebut menemukan bahwa pola pemilih masyarakat di level nasional didominasi oleh pola priomordial dan pasca Orde Baru beranjak ke pola rasional. Begitu juga dengan kajian di tingkat lokal (Kristiadi, 1994; King, 2003; dan Haryanto, 2014) yang juga menemukan pergeseran pola perilaku memilih masyarakat yang terjadi di level nasional juga terjadi di level lokal. Namun, kajian perilaku memilih masyarakat dalam tulisan ini menyanggah kajian sebelumnya bahwa pergeseran pola pemilih tidak sepenuhnya terjadi. Berikut beberapa kajian sebelumnya terkait perilaku memilih di Indonesia.

Penelitian yang menjadi dasar perilaku memilih masyarakat di Indonesia, Geertz dalam karyanya "The Religion of Java" menjelaskan bahwa perilaku memilih di Jawa dengan pendekatan aliran. Pendekatan aliran ini menemukan bahwa masyarakat di Mojokuto terbagi menjadi tiga hal dalam memilih, yaitu abangan, santri, dan priyayi (Geertz, 1960).

Di tahun 1992, Gaffar dalam karyanya "Javanese Voters: A Case Study of Election Under a Hegemonic Party System" menguatkan bahwa pendekatan aliran masih menjadi konsumsi utama dalam perilaku memilih. Penelitian ini dilakukan di desa Brobanti, di wilayah kota Yogyakarta melihat perilaku memilih masyarakat melalui aspek sosioreligius yang pada saat itu menguasai masyarakat Jawa, isu partai, dan aspek kepemimpinan. Tulisannya yang berjudul "Half-Hearted Reform: 
Electoral Institutions and the Struggle for Democracy" (King, 2003) dan tulisan "Indonesian Electoral Behaviour: A Statistical Perspective" (Ananta \& Suyadinata, 2004) menunjukkan bahwa variabel socioreligious, socio-cultural, ataupun sosio-economic masih menunjukkan perilaku memilih masyarakat.

Penemuan dari Dwight King dan Anies Baswedan menyimpulkan bahwa politik aliran atau pola memilih yang berdasarkan agama masih relevan dalam perilaku memilih masyarakat di Indonesia. Dalam penelitiannya, King membagi antara dua identitas berdasarkan keagamaan. Penelitian yang membandingkan dua pemilu, yaitu pemilu 1955 dan 1999 menunjukkan bahwa pembagian politik aliran antara santri dan abangan serta pembagian antara santri tradisionalis dengan modernis (Yustiningrum dan Ichwanuddin, 2015, p. 119).

Di level lokal kota/kabupaten tahun 1999 dan 2004, tulisan Baswedan yang berjudul Sirkulasi Suara Dalam Pemilu 2004 tersebut ditemukan bukti empiris bahwa masyarakat mampu berpindah ke partai lain namun perpindahan tersebut tidak diikuti dengan ideologi partainya. Penelitian Baswedan menyibak adanya hubungan yang berarti bahwa pemilih menentukan pilihannya pada partai berbasis agama, baik Islam maupun Kristen dan partai nasionalis. Misalnya, sirkulasi partai PAN, PKB, dan PPP yang mana pendukungnya berpindah partai namun tidak ke partai berideologi nasional (Baswedan, 2004).

Tulisan yang berjudul "Pemilihan Umum dan Perilaku Pemilih: Suatu Studi Kasus Tentang Perilaku Pemilih di Kotamadya Yogyakarta dan Kabupaten Banjarnegara, Jawa Tengah pada Pemilihan Umum 1971-1987” menggunakan pendekatan sosio-kultural yang merupakan gabungan antara pendekatan sosiologis dan psikologis. Tulisan ini menemukan alasan masyarakat memilih berdasar pada aspek panutan dan identifikasi kepartaian (Kristiadi, 1994). Tulisan yang berjudul "Kuasa Rakyat: Analisis tentang Perilaku Memilih dalam Pemilihan 
Legislatif dan Presiden Indonesia Pasca Orde Baru", Mujani dan Liddle melihat bahwa orientasi keagamaan atau aliran tidak lagi hal utama dalam perilaku memilih. Penelitian yang dilakukan di level nasional menemukan bahwa model ekonomi dan psikologis mampu menjawab dinamika perilaku memilih di Indonesia. Hal ini menunjukkan kajian perilaku memilih di Indonesia telah bergerak dari pendekatan sosiologi yang menekankan pada pendekatan yang lebih rasional (Mujani, Liddle, \& Ambardi, 2012, p. 454).

Leo Agustino dan Mohammad Agus Yusoff yang menulis mengenai Pemilihan Umum dan Perilaku Pemilih: Analisis Pemilihan Presiden 2009 di Indonesia melihat bahwa pendekatan perilaku pemilih berubah ketika terjadi Reformasi pada tahun 1998. Pemilih di Indonesia telah mulai bergerak dari primordial menuju perilaku pemilih rasional yang bersifat semu (Agustino \& Yusoff, 2009). Perubahan perilaku memilih di Indonesia tidak hanya berada di level nasional namun juga terjadi di skala lokal. Kemudian, tulisan Haryanto yang berjudul Kebangkitan Party ID: Analisis Perilaku Memilih dalam Politik Lokal di Indonesia menemukan bahwa kajian di skala lokal telah berubah dari pendekatan sosiologi, yang selama ini menguasai perilaku memilih di Indonesia. Haryanto menggunakan pendekatan psikologi dalam kajian tersebut dan menemukan bahwa pemilih cenderung mengindentikkan diri dengan partai, kemudian menentukan pilihan suaranya kepada kandidat yang diusung oleh partainya (Haryanto, 2014).

Dari beberapa penelitian te terlihat bahwa kajian perilaku memilih di Indonesia awalnya didominasi oleh pola priomordial. Pola primordialini dalam bentuk politik aliran yang berbasis pada agama maupun budaya. Meskipun ada perubahan memilih (khususnya, partai) tetapi perubahan tersebut tidak bersamaan dengan perubahan ideologi partai tersebut. Masyarakat hanya berpindah dari satu partai ke partai lain yang masih dalam ideologi yang sama. Namun, pola primordial ini mulai bergerak ke arah rasional yang melihat ke faktor ekonomi dan 
psikologis pasca Orde Baru.

\section{Perilaku Memilih}

Beberapa ahli mendefinisikan perilaku memilih dengan berbagai macam pendapat. Misalnya Jack Plano mengatakan bahwa perilaku memilih adalah bentuk dari perilaku politik yang terbuka. Menurut Huntington dan Nelson, perilaku memilih merupakan aktivitas elektoral yang bertujuan memengaruhi proses pemilihan umum, baik dalam bentuk pemberian suara maupun ikut serta dalam kampanye (Valentina, 2009). Pemberian suara dalam pemilu merupakan salah satu bentuk partisipasi politik. Dalam negara demokrasi, voting menjadi ukuran paling minimum dari partisipasi politik konvensional. Walaupun demikian, pengaruh voting dalam sistem politik sangat besar bila dibandingkan dengan partispasi politik lainnya. Ini karena berpengaruh pada suatu formasi kekuasaan tertentu yang mengendalikan bekerjanya sistem politik. Dengan voting, maka dapat membatasi kekuatan-kekuatan politik yang muncul dalam panggung kekuasaan politik (Pamungkas, 2010).

Penelitian perilaku memilih dapat menggunakan beberapa penawaran pendekatan. Afan Gaffar membagi pada dua pendekatan. Pertama, pendekatan sosiologi yang dikenal sebagai Mazhab Columbia, yang menekankan pada faktor sosiologis. Kedua, pendekatan psikologi atau yang dikenal juga dengan Mazhab Michigan, yang menekankan pada faktor psikologis (Gaffar, 1992, p. 4-9). Berbeda dengan Afan Gaffar, Lau dan Redlawsk mengemukakan bahwa ada empat model perilaku memilih. Pertama, model pilihan rasional (rational choice), diasumsikan bahwa orang-orang secara saksama mengevaluasi seluruh informasi dan membuat pilihan pemilih berdasarkan kepentingan diri. Kedua, model early socialization and cognitive consistency, yang menggambarkan pemilih cenderung tidak peduli pada politik dan memiliki sedikit pengetahuan mengenai politik. 
Model ketiga yang ditawarkan Lau dan Redlawsk adalah Fast and Frugal Decision Making. Model ini melihat pemilih memiliki pengetahuan politik yang cukup sehingga tidak berfokus pada proses pengumpulan informasi tetapi pada proses memahami informasi yang didapat. Model keempat, bounded rationality and intuitive decision making. Perilaku memilih model ini adalah pemilih hanya mengumpulkan sedikit informasi yang diperolehnya selama kampanye berlangsung dan tidak berusaha mencari informasi mengenai alternatif pilihan (Lau \& Redlawsk, 2006, p. 6-14). Namun secara garis besar, pendekatan dalam mengkaji perilaku memilih terbagi atas tiga pendekatan, yaitu pendekatan sosial struktural (sosiologis), sosial psikologis, dan pilihan rasional atau ekonomi politik (Mujani, et.al., 2012).

Tulisan ini menggunakan pendekatan sosiologis atau yang dikenal dengan mahzab Colombia untuk melihat fenomena di Kutai Kartanegara dalam pilgub Kalimantan Timur 2018. Pendekatan ini berkiblat kepada nilai-nilai sosiologis yang melekat pada diri seseorang yang mampu memengaruhi perilaku seseorang dalam politik. Nilai-nilai sosiologis tersebut, menurut Larry Martin Bartels terdiri dari etnis, agama, daerah, kelas sosial, tradisi keluarga, dan lain-lain (Leighley, 2012, p. 240). Selain itu, perilaku memilih melalui pendekatan sosiologis juga melihat pada keadaan demografi dan sosial ekonomi, seperti jenis kelamin, tempat tinggal yang meliputi pemukiman di perkotaan maupun perdesaan, pekerjaan, pendidikan, dan pendapatan. Pomper juga melihat bahwa terdapat korelasi antara faktor sosial ekonomi pemilih dan keluarga dalam perilaku pemilih seseorang. Misalnya, prefensi politik keluarga (berdasarkan agama, tempat tinggal, kelas sosial, demografis) dimana preferensi pilihan anak akan cenderung sesuai dengan preferensi orang tua mereka (Efriza, 2012, p. 494).

Model pendekatan sosiologis ini merupakan model yang dikembangkan atas dasar teori Lingkaran Sosial yang dikembangkan 
oleh George Simmel. Teori ini berbicara mengenai seseorang yang tinggal dalam lingkungan sosial tertentu akan cenderung ikut pada keadaan lingkungan sosial yang membentuknya. Dengan demikian, pilihan politik seseorang tersebut juga kuat dipengaruhi oleh struktur sosial yang melingkupinya (Roth, 2008, p. 24).

\section{Pemilihan Gubernur dan Wakil Gubernur Kalimantan Timur 2018}

Pemilihan gubernur dan wakil gubernur di Kalimantan Timur dilaksanakan pada tanggal 27 Juni 2018. Secara resmi, empat pasang calon disahkan dalam pemilihan ini. Pasangan nomor urut 1 adalah Andi Sofyan Hasdam dan Rizal Effendi. Andi Sofyan Hasdam sebelumnya adalah walikota Bontang sedangkan Rizal Effendi merupakan walikota Balikpapan. Rizal Effendi awalnya bukan calon wakil gubernur mendampingi Andi Sofyan Hasdam. Rizal Effendi ditunjuk untuk menggantikan Nusyirwan Ismail yang meninggal dunia tanggal 27 Februari 2018.

Pasangan nomor urut 2 adalah Syaharie Jaang dan Awang Ferdian Hidayat. Syaharie Jaang merupakan walikota Samarinda dua periode dari tahun 2010-2021 sedangkan wakilnya Awang Ferdian Hidayat adalah anggota DPR RI 2014-2019. Awang Ferdian Hidayat adalah putra dari Awang Faroek Ishak yang merupakan gubernur Kalimantan Timur dua periode tahun 2008-2018. Pasangan nomor urut 3, yaitu Isran Noor dan Hadi Mulyadi. Isran Noor adalah seorang bupati Kutai Timur dari tahun 2009-2015 sedangkan Hadi Mulyadi adalah anggota DPR RI tahun 2014-2019. Pasangan nomor urut 4 adalah Rusmadi Wongso dan Safaruddin. Rusmadi sebelumnya adalah seorang birokrat sebagai Sekretaris Daerah provinsi Kalimantan Timur 2016-2018 sedangkan Safaruddin sebelumnya berkarir di kepolisian dan menjabat sebagai Kepala Polisi Daerah Kalimantan Timur 2015-2018. 
Setiap pasangan calon didukung oleh partai politik yang relatif seimbang jumlahnya. Pasangan Andi Sofyan Hasdam dan Rizal Effendi didukung oleh partai Golongan Karya (Golkar) dan partai Nasional Demokrat (Nasdem). Pasangan nomor urut 2 adalah Syaharie Jaang dan Awang Ferdian Hidayat didukung tiga partai, yaitu partai Demokrat, Partai Persatuan Pembangunan (PPP) dan Partai Kebangkitan Bangsa (PKB). Kemudian pasangan nomor urut 3, Isran Noor dan Hadi Mulyadi didukung oleh tiga partai politik, yaitu partai Gerakan Indonesia Raya (Gerindra), Partai Keadilan Sosial (PKS), dan Partai Amanat Nasional (PAN). Sedangkan dua partai politik, yaitu Partai Demokrasi Indonesia Perjuangan (PDIP) dan partai Hati Nurani Rakyat (Hanura) solid mendukung pasangan nomor urut 4, Rusmadi Wongso dan Safaruddin (KPU Kalimantan Timur, 2018).

Berdasarkan etnis, setiap pasangan calon memiliki etnis yang beragam, mewakili hampir seluruh etnis masyarakat Kalimantan Timur. Pasangan nomor 1, Andi Sofyan Hasdam dan Rizal Effendi merupakan keturunan dari etnis Bugis. Pasangan nomor 2, yaitu Syaharie Jaang dan Awang Ferdian Hidayat adalah pasangan antara suku Dayak dan suku Kutai. Pasangan ke-3, Isran Noor dan Hadi Mulyadi adalah pasangan dari suku Kutai dan suku Banjar. Sedangkan pasangan ke-4, Rusmadi Wongso dan Safaruddin adalah suku Jawa dan suku Bugis. Sedangkan berdasarkan identitas agama, keempat pasangan calon gubernur dan wakil gubernur tersebut memiliki kesamaan identitas keagamaan, yaitu Islam.

Di level provinsi, kemenangan diraih oleh pasangan Isran Noor dan Hadi Mulyadi dengan perolehan suara 417.711. Pasangan ke-4, Rusmadi Wongso dan Safaruddin menjadi pemenang kedua dengan perolehan suara 324.226. Syaharie Jaang dan Awang Ferdian Hidayat menduduki posisi ketiga dengan mengumpulkan 302.987 suara. Sedangkan posisi terakhir diduduki oleh pasangan Andi Sofyan Hasdam dan Rizal Effendi dengan perolehan 288.166 suara (Lihat di Tabel 1). Pasangan 
yang sebelumnya adalah kepala daerah tidak mendapat dukungan dari masyarakat yang mereka pimpin. Tiga dari empat pasangan calon gubernur dan wakil gubernur gagal memperoleh pundi-pundi suara di wilayah asal mereka. Misalnya, Rizal Effendi yang merupakan walikota Balikpapan kalah di daerah yang dipimpinnya selama dua periode tersebut. Begitu juga dengan Syaharie Jaang yang merupakan walikota Samarinda, juga gagal menjadikan Jaang sebagai pemenang di ibu kota provinsi Kalimantan Timur ini. Pemenang kontestasi Isran Noor yang juga menjabat bupati Kutai Timur dua periode kepemimpinan juga gagal mendapat suara mayoritas di wilayah Kutai Timur ini (Lihat di Tabel 2).

Tabel 1. Hasil Perolehan Suara Pemilihan Gubernur dan Wakil Gubernur Kalimantan Timur 2018 di Tingkat Provinsi

\begin{tabular}{|l|l|c|c|}
\hline No. & Nama Pasangan Calon & Perolehan Suara & Persentase \\
\hline 1. & Andi Sofyan Hasdam-Rizal Effendi & 288.166 & $21,61 \%$ \\
\hline 2. & Syaharie Ja'ang-Awang Ferdian Hidayat & 302.987 & $22,72 \%$ \\
\hline 3. & Isran Noor-Hadi Mulyadi & 417.711 & $31,33 \%$ \\
\hline 4. & Rusmadi-Safaruddin & 324.226 & $24,32 \%$ \\
\hline Jumlah & $\mathbf{1 . 3 3 3 . 0 9 0}$ & $\mathbf{1 0 0} \%$ \\
\hline
\end{tabular}


Tabel 2. Hasil Perolehan Suara Pemilihan Gubernur dan Wakil Gubernur Kalimantan Timur 2018 di Kabupaten/Kota Se-Kalimantan Timur

\begin{tabular}{|l|l|c|c|c|c|}
\hline No. & $\begin{array}{l}\text { Nama Kabupaten/ } \\
\text { Kota }\end{array}$ & $\begin{array}{c}\text { Andi } \\
\text { Sofyan } \\
\text { Hasda } \\
- \text { Rizal } \\
\text { Effendi }\end{array}$ & $\begin{array}{c}\text { Syaharie } \\
\text { Jaang - } \\
\text { Awang } \\
\text { Ferdian } \\
\text { Hidayat }\end{array}$ & $\begin{array}{c}\text { Isran Noor } \\
\text { - Hadi } \\
\text { Mulyadi }\end{array}$ & $\begin{array}{c}\text { Rusmadi - } \\
\text { Safaruddin }\end{array}$ \\
\hline 1. & Berau & 13.060 & 23.476 & 23.650 & 15.738 \\
\hline 2. & Kota Balikpapan & 82.488 & 22.115 & 68.647 & 83.491 \\
\hline 3. & Kota Bontang & 26.882 & 5.864 & 19.423 & 13.097 \\
\hline 4. & Kota Samarinda & 43.575 & 81.741 & 113.372 & 73.746 \\
\hline 5. & Kutai Barat & 3.198 & 25.992 & 9.891 & 24.657 \\
\hline 6. & Kutai Kartanegara & 58.007 & 59.736 & 96.045 & 57.729 \\
\hline 7. & Kutai Timur & 17.254 & 32.464 & 30.949 & 20.296 \\
\hline 8. & Mahakam Ulu & 404 & 7.434 & 2.748 & 2.917 \\
\hline 9. & Paser & 20.716 & 24.257 & 29.715 & 17.185 \\
\hline 10. & Penajam & 22.582 & 19.908 & 23.271 & 15.370 \\
\hline Jumlah Paser & Utara & $\mathbf{2 8 8 . 1 6 6}$ & $\mathbf{3 0 2 . 9 8 7}$ & $\mathbf{4 1 7 . 7 1 1}$ & $\mathbf{3 2 4 . 2 2 6}$ \\
\hline
\end{tabular}

Sumber: KPUD Kalimantan Timur

\section{Kehadiran Rita dalam Pemilihan Gubernur Kalimantan Timur}

Nama Rita di Kutai Kartanegara cukup dikenal oleh masyarakat jauh sebelum menjabat sebagai bupati Kutai Kartanegara dua periode. Munculnya Rita dikarenakan sosok Hasan Rais Syaukani yang merupakan ayah kandung Rita, yang juga bupati di Kutai Kartanegara dua periode. Setelah Syaukani tidak lagi menjabat sebagai bupati, sosok Rita muncul di permukaan yang dipersiapkan menggantikan Syaukani. Hal ini terbukti terpilihnya Rita di tahun 2010 dan 2015. Di tahun 2015, Rita memperoleh persentase suara yang besar, yaitu 89,38\% 
(KPU, 2015). Perolehan suara ini juga tercatat dalam Museum Rekor Indonesia (MURI) yang memberikan dua penghargaan kepada Rita Widyasari. Pertama, Rita Widyasari sebagai perempuan calon kepala daerah dari jalur independen yang memperoleh persentase terbanyak pada pilkada serentak 2015. Kedua, sebagai perempuan calon kepala daerah dari jalur independen yang memperoleh persentase $100 \%$ di TPS terbanyak. Perolehan 100\% ini terdapat di 14 TPS (MURI, 2018).

Kepopuleran Rita di Kutai Kartanegara melalui beberapa kegiatan yang dilakukan membawa namanya dikenal oleh masyarakat Kalimantan Timur. Misalnya saja, kegiatan Festival Erau² dan Rock in Borneo $^{3}$ yang diadakan dalam skala besar. Tidak hanya itu, setumpuk aktivitas Rita di pemerintahan juga membuatnya sering mendapatkan penghargaan, baik skala nasional maupun internasional. Kemampuan komunikasi Rita dengan masyarakat telah membuat Rita mendapatkan posisi yang baik di hati masyarakat. Tidak hanya masyarakat Kutai Kartanegara tetapi masyarakat Kalimantan Timur pun mengenalnya sebagai sosok baru yang membawa angin segar perubahan.

Keiinginan Rita menjadi gubernur Kalimantan Timur dan berkantor di Samarinda telah diketahui oleh masyarakat Kutai Kartanegara dalam setiap sambutannya di beberapa kegiatan sebagai bupati. Kehadiran Rita di bursa calon gubernur Kalimantan Timur membuat beberapa spekulasi di beberapa kalangan masyarakat. Masyarakat meyakini dengan kepopuleran Rita atas aktivitasnya, baik di dalam pemeritahan maupun di luar pemerintahan akan mudah memenangkan kontestasi

2 Festival Erau adalah kegiatan yang sangat populer di Kutai Kartanegara yang merupakan kegiatan budaya masyarakat Suku Kutai. Sekarang, Erau dilaksanakan sebagai tradisi dalam memelihara dan pelestarian budaya dalam bentuk pesta rakyat dan festival budaya. Seiring dengan perkembangannya, Erau tidak hanya menampilkan kebudayaan lokal namun mengundang peserta dari negara lain untuk hadir di Festival Erau, yang kemudian dikenal dengan EIFAF (Erau nternational Folk Arts Festival).

3 Rock In Borneo adalah pagelaran musik terbesar di Kalimantan yang mengundang grup band papan atas dunia dan musisi lokal. Pagelaran musik ini juga memecahkan rekor MURI sebagai pagelaran musik rock gratis terbesar. 
tersebut. Hal ini juga dijelaskan oleh beberapa lembaga survei yang menempatkan Rita di posisi teratas, seperti INES, Indopoling Network, (Beritasatu, 2018) dan Indo Barometer, Pusdeham, LSI, Chartra Politika (Tribunnews, 2018).

Naiknya Rita sebagai calon gubernur di Kalimantan Timur membawa angin segar dan harapan baru bagi masyarakat Kalimantan Timur. Tingginya harapan masyarakat tersebut karena persepsi masyarakat memandang Rita mampu melakukan pembangunan di segala bidang. Di Kutai Kartanegara, pembangunan tidak hanya pembangunan fisik daerah tetapi juga pembangunan manusianya. Pembangunan tersebut tidak hanya terpusat di perkotaan tetapi juga di pedalaman Kutai Kartanegara. Maka dari itu, pilihan masyarakat dalam memilih Rita di tahun kedua pencalonannya menjadi bupati menggiring perilaku memilih masyarakat berkembang dari sosiologis ke arah psikologis dan juga rasional (Novianto, 2017). Masyarakat memilih Rita karena jelasnya pembangunan yang dirasakan hampir seluruh masyarakat. Program-program yang terangkum ke dalam Visi Gerbang Raja ${ }^{4}$ Jilid I dan II mampu menjadikan Rita sosok populer di Kutai Kartanegara khususnya, dan Kalimantan Timur (Kaltim) pada umumnya.

Langkah Rita menuju "Kaltim 1" tidaklah mulus. Beberapa waktu setelah deklarasi, Rita sebagai calon gubernur yang diusung oleh partai Golkar terpaksa terhenti. Rita tersandung kasus hukum dalam bentuk suap dan gratifikasi terkait izin pertambangan di Kutai Kartanegara (Linawati, 2018). Dengan demikian, Rita tidak dapat lagi melanjutkan niat menjadi gubernur tersebut. Terkait hal ini, masyarakat Kutai Kartanegara yang mengaharapkan Rita maju sebagai gubernur menjadi kecewa dengan keadaan tersebut. Namun, masyarakat tetap menerima kenyataan dan menyerahkan kepada ketentuan hukum yang berlaku.

4 Gerbang Raja adalah singkatan kata dalam visi kabupaten Kutai Kartanegara di masa kepemimpinan Rita. Gerbang Raja sendiri adalah Gerakan Pembangunan Rakyat Sejahtera. 
Keadaan yang dialami Rita ketika masih duduk sebagai bupati dan menuju kursi gubernur juga pernah dihadapi oleh ayah Rita sendiri. Hasan Rais Syaukani juga terlibat masalah hukum terkait korupsi yang dilakukannya. Kasus ini dialami oleh Syaukani ketika periode kedua menjabat sebagai bupati di Kutai Kartanegara. Syaukani terlibat dalam penyalahgunaan dana perangsang pungutan sumber daya alam (migas), dan terkait studi kelayakan pembangunan Bandara Kutai di Loa Kulu, serta penggunaan dana pos anggaran terkait kesejahteraan masyarakat (Simanjuntak, 2017, p. 2).

Pasca Rita gagal berkantor di Samarinda, perpolitikan di Kalimantan Timur kembali bergejolak. Keadaan ini dapat menjadi kesempatan baik bagi lawan politik Rita yang berhasrat tinggi untuk menjadi gubernur di Kalimantan Timur. Khususnya di Kutai Kartanegara, tidak ada lagi calon yang berasal dari daerah ini maupun calon yang ditunjuk sebagai pengganti Rita. Keresahan masyarakat Kutai Kartanegara timbul terkait siapa yang akan dipilih nantinya dalam pesta demokrasi di Kalimantan Timur. Hingga akhirnya terdapat empat pasang calon yang terpilih untuk mengikuti pertarungan memperebutkan kursi "Kaltim 1". Di antaranya adalah Isran Noor dan Hadi Mulyadi, Andi Sofyan Hasdam dan Nusyirwan Ismail, Rusmadi Wongso dan Safaruddin, serta Syaharie Jaang dan Awang Ferdian Hidayat.

Runtuhnya dinasti Syaukani di Kutai Kartanegara dimana kesan yang dibangun oleh pemimpin di daerah ini adalah sangat merakyat. Kemampuan Syaukani maupun Rita tidak diragukan lagi karena rakyat Kutai Kartanegara begitu mengidolakan sosok mereka ini. Syaukani dianggap sebagai bapak pembangunan Kutai Kartanegara dan Rita sebagai pengganti ayahnya untuk memajukan Kutai Kartanegara. Hingga saat sekarang, sebagian masyarakat mayakini bahwa baik Syaukani maupun Rita sengaja dijebak untuk dijatuhkan. Masyarakat pun masih menganggap Rita untuk dapat memimpin masyarakat Kutai Kartanegara dan juga Kalimantan Timur meskipun kedua tokoh ini 
positif melanggar Undang-Undang yang berlaku.

"Dari era bapaknya Rita hingga era Rita, kami yakin bahwa mereka sengaja dijebak untuk dijatuhkan. Kami melihat bahwa Syaukani dan Rita sama-sama mempunyai niat yang baik untuk membangun Kukar dan menguasai aset yang dimiliki Kukar dikuasai oleh Kukar sendiri."

(Wawancara dengan Khairul Anwar, warga Tenggarong, 10 Oktober 2018)

Warga lain juga mengatakan hal yang sama bahwa Rita sebenarnya tidak bersalah dalam kasus ini. Ini adalah akibat perbuatan orangorang di belakang Rita.

"Rita itu seperti dikuasai oleh orang-orang di 'belakang' Rita. Mereka yang sebenarnya mengatur Rita dan hingga akhirnya kebablasan. Kebablasan itu menyeret Rita terkena kasus yang sekarang menimpanya."

(Wawancara dengan Sopan Sopian, warga Muara Muntai, 15 November 2018)

\section{Pemilihan Gubernur dan Wakil Gubernur Kalimantan Timur di Kabupaten Kutai Kartanegara}

Perolehan suara yang didapat oleh keempat pasangan calon gubernur dan wakil gubernur di tingkat provinsi relatif sama dengan perolehan suara di tingkat kabupaten Kutai Kartanegara. Namun, sedikit perbedaan yang dialami pasangan Isran Noor dan Hadi Mulyadi yang persentase kemenangannya lebih tinggi empat persen dan persentase yang lebih kecil tiga persen yang dialami oleh Rusmadi dan Safaruddin di kabupaten Kutai Kartanegara ketimbang perolehan di tingkat provinsi. Meskipun Rusmadi dan Safaruddin berada di posisi kedua di 
tingkat provinsi namun di kabupaten Kutai Kartanegara pasangan ini berada di posisi terbawah (KPUD Kutai Kartanegara, 2018).

Tabel 3. Hasil Perolehan Suara Pemilihan Gubernur dan Wakil Gubernur Kalimantan Timur 2018 di Kabupaten Kutai Kartanegara

\begin{tabular}{|c|l|c|c|}
\hline No. & Nama Pasangan Calon & Perolehan Suara & Persentase \\
\hline 1. & Andi Sofyan Hasdam-Rizal Effendi & 58.007 & $21,36 \%$ \\
\hline 2. & Syaharie Ja'ang-Awang Ferdian Hidayat & 59.736 & $22,01 \%$ \\
\hline 3. & Isran Noor-Hadi Mulyadi & 96.045 & $35,37 \%$ \\
\hline 4. & Rusmadi-Safaruddin & 57.729 & $21,26 \%$ \\
\hline Jumlah & $\mathbf{2 7 1 . 5 1 7}$ & $\mathbf{1 0 0 \%}$ \\
\hline
\end{tabular}

Sumber: KPUD Kabupaten Kutai Kartanegara

Kemenangan setiap pasangan relatif didominasi oleh keunggulan Isran Noor dan Hadi Mulyadi. Pasangan ini unggul di 11 kecamatan dari 18 kecamatan yang ada di Kutai Kartanegara. Isran Noor dan Hadi Mulyadi berhasil menjadi juara di kecamatan Tenggarong, Sebulu, Sanga-Sanga, Muara Wis, Muara Muntai, Muara Kaman, Loa Kulu, Loa Janan, Kota Bangun, Kenohan, dan Kembang Janggut. Pemenang kedua di Kutai Kartanegara, yaitu pasangan Syaharie Ja’ang-Awang Ferdian Hidayat hanya mampu menang dominan di satu kecamatan bagian hulu ${ }^{5}$ Kutai Kartanegara, yaitu kecamatan Tabang. Pasangan Andi Sofyan Hasdam-Rizal Effendi yang berada di posisi ketiga ini unggul di tiga kecamatan, yaitu Marang Kayu, Muara Badak, dan Muara Jawa. Ketiga wilayah ini berada di pesisir Kutai Kartanegara. Sedangkan posisi Rusmadi-Safaruddin yang berada di posisi terakhir unggul di tiga kecamatan yang meliputi wilayah Anggana, Samboja, dan Tenggarong Seberang. Maka, dapat dipetakan bahwa kemenangan setiap kandidat tidaklah sama. Kecuali pasangan Isran Noor dan Hadi

5 Di Kutai Kartanegara, istilah Hulu merupakan istilah wilayah yang berada di hulu Sungai Mahakam. 
Mulyadi yang berhasil unggul di setiap wilayah Kutai Kartanegara baik hulu, tengah, maupun pesisir. Pasangan Syaharie Ja'ang dan Awang Ferdian Hidayat berjaya di wilayah hulu, pasangan Rusmadi dan Safaruddin mampu mengumpulkan di wilayah tengah dan pesisir Kutai Kartanegara, sedangkan pasangan Andi Sofyan Hasdam dan Rizal Effendi hanya unggul di wilayah pesisir.

Tabel 4. Hasil Perolehan Suara Pemilihan Gubernur dan Wakil Gubernur Kalimantan Timur 2018 Masing-masing Kecamatan di Kabupaten Kutai Kartanegara

\begin{tabular}{|l|l|c|c|c|c|c|}
\hline No. & Nama & $\begin{array}{c}\text { Andi } \\
\text { Sofyan } \\
\text { Kasdam- } \\
\text { Rizal } \\
\text { Effendi }\end{array}$ & $\begin{array}{c}\text { Syaharie } \\
\text { Jwang- } \\
\text { Ferdian } \\
\text { Hidayat }\end{array}$ & $\begin{array}{c}\text { Isran } \\
\text { Noor- } \\
\text { Hadi } \\
\text { Mulyadi }\end{array}$ & $\begin{array}{c}\text { Rusmadi- } \\
\text { Safaruddin }\end{array}$ & Jumlah \\
\hline 1. & Anggana & 2.558 & 2.777 & 2.299 & 4.880 & $\mathbf{1 2 . 7 6 7}$ \\
\hline 2. & Kembang & 1.481 & 2.311 & 2.814 & 1.472 & $\mathbf{8 . 3 4 8}$ \\
\hline 3. & Kenohan & 791 & 1.771 & 2.029 & 539 & $\mathbf{5 . 2 8 8}$ \\
\hline 4. & Kota Bangun & 2.866 & 3.148 & 6.883 & 1.878 & $\mathbf{1 5 . 4 5 2}$ \\
\hline 5. & Loa Janan & 5.851 & 7.281 & 7.745 & 4.630 & $\mathbf{2 6 . 6 4 6}$ \\
\hline 6. & Loa Kulu & 4.109 & 4.520 & 6.599 & 3.380 & $\mathbf{1 9 . 7 4 6}$ \\
\hline 7. & Marang Kayu & 4.854 & 2.255 & 2.538 & 1.851 & $\mathbf{1 1 . 6 5 4}$ \\
\hline 8. & Muara Badak & 5.723 & 3.869 & 3.711 & 4.007 & $\mathbf{1 7 . 5 8 8}$ \\
\hline 9. & Muara Jawa & 4.846 & 2.873 & 4.066 & 2.961 & $\mathbf{1 5 . 1 6 3}$ \\
\hline 10. & Muara Kaman & 2.578 & 2.515 & 5.379 & 2.638 & $\mathbf{1 3 . 5 1 6}$ \\
\hline 11. & Muara Muntai & 745 & 1.070 & 4.158 & 673 & $\mathbf{7 . 0 9 3}$ \\
\hline 12. & Muara Wis & 550 & 741 & 2.458 & 483 & $\mathbf{4 . 3 8 8}$ \\
\hline 13. & Samboja & 6.730 & 6.176 & 5.478 & 6.970 & $\mathbf{2 6 . 2 7 4}$ \\
\hline 14. & Sanga-Sanga & 1.177 & 1.566 & 2.237 & 1.255 & $\mathbf{6 . 4 9 2}$ \\
\hline
\end{tabular}




\begin{tabular}{|l|l|c|c|c|c|c|}
\hline 15. & Sebulu & 2.353 & 2.593 & 5.926 & 3.324 & $\mathbf{1 4 . 8 2 3}$ \\
\hline 16. & Tabang & 668 & 1.745 & 973 & 603 & $\mathbf{4 . 0 7 1}$ \\
\hline 17. & Tenggarong & 6.815 & 6.942 & 22.098 & 7.499 & $\mathbf{4 5 . 9 6 3}$ \\
\hline 18. & $\begin{array}{l}\text { Tenggarong } \\
\text { Seberang }\end{array}$ & 3.312 & 5.583 & 8.659 & 8.686 & $\mathbf{2 7 . 4 6 2}$ \\
\hline
\end{tabular}

Sumber: KPUD Kabupaten Kutai Kartanegara

\section{Basis Agama dalam Perilaku Memilih Masyarakat di Kutai Kartanegara}

Wawancara yang dilakukan dengan masyarakat di wilayah Tenggarong memperlihatkan bahwa fenomena yang terjadi di DKI Jakarta (aksi bela Islam) juga membuat masyarakat di wilayah ini memilih pemimpin yang mendekati kriteria yang digaungkan oleh inisiator, yaitu Front Pembela Islam (FPI) atau Gerakan Nasional Pengawal Fatwa Majelis Ulama Indonesia (GNPF-MUI) yang terdiri dari FPI, Hizbut Tahrir Indonesia (HTI), Forum Umat Islam (FUI), Majelis Mujahidin Indonesia (MMI), Tarbiyah/Partai Keadilan Sejahtera (PKS) (Pamungkas dan Octaviani, 2017, p. 68). Hadi Mulyadi adalah sosok religius yang mampu membawa kemenangan pasangan Isran Noor dan Hadi Mulyadi ini menang di 11 kecamatan dan memimpin kemenangan di Kutai Kartanegara.

"Di televisi sering diberitakan tentang memilih pemimpin muslim bagi pemeluk Islam. Anjuran ini menguat setelah adanya kasus penistaan agama oleh Ahok. Di media sosial sejak kejadian itu maka banyak muncul kajian-kajian kriteria memilih pemimpin bagi pemeluk Islam. Hal itu juga berpengaruh dalam memilih pemimpin di Kaltim. Saya melihat bahwa sosok Hadi Mulyadi adalah calon yang tepat untuk memimpin Kaltim."

(Wawancara dengan Riri, warga Tenggarong, 08 Oktober 
2018)

Meskipun keseluruhan pasangan calon gubernur dan wakil gubernur adalah Muslim, namun sosok kereligiusan Hadi Mulyadi lebih kuat. Ini disebabkan oleh latar belakang Hadi Mulyadi sendiri yang merupakan politisi asal salah satu partai inisiator Gerakan Bela Islam di DKI Jakarta, PKS. Masyarakat meyakini bahwa ketika Kalimantan Timur dipimpin oleh tokoh Muslim, maka aspirasi mereka dan komunikasi antara masyarakat dapat berjalan dengan baik. Selain itu hal utama adalah ketaatan yang dilakukan oleh masyarakat untuk menjalankan syariat Islam untuk memilih pemimpin yang Muslim dan selalu memperhatikan kondisi umat.

"Saya memilih dalam pilgub Kaltim kemarin bukan karena Isran Noor-nya namun karena melihat sosok pendampingnya, Pak Hadi Mulyadi. Pak Hadi itu terlihat lebih alim dan cara bicaranya pun tenang. Sehingga menurut saya Pak Hadi cocok jadi pemimpin”.

(Wawancara dengan Ida, warga Tenggarong, 08 Oktober 2018)

Di kecamatan Muara Badak, basis identitas agama ini tampak semakin kuat. Di desa Badak Baru misalnya, dimenangkan oleh pasangan Isran Noor dan Hadi Mulyadi. Hal ini diketahui dari salah satu tim sukses Syaharie Jaang dan Awang Ferdian Hidayat yangmana kemenangan diperoleh oleh pasangan nomor 3. Desa Badak Baru dimasuki oleh pasangan Syaharie Ja'ang-Awang Ferdian Hidayat dan Rusmadi-Safaruddin untuk berkampanye. Sedangkan pasangan Isran Noor dan Hadi Mulyadi tidak pernah memasuki wilayah ini untuk berkampanye. Namun demikian, kemenangan mampu diperoleh oleh Isran Noor dan Hadi Mulyadi. Kemenangan pasangan Isran Noor dan Hadi Mulyadi berhasil dikarenakan masyarakat melihat Hadi Mulyadi sebagai tokoh yang religius ketimbang Isran Noor sebagai calon 
gubernur dan pasangan calon gubernur-wakil gubernur lainnya.

\section{Basis Etnis dalam Perilaku Memilih Masyarakat di Kutai Kartanegara}

Argumen dalam bagian ini adalah bahwa perilaku memilih masyarakat di level lokal masih belum sepenuhnya rasional. Jika di level nasional runtuhnya kekuasaan Soeharto terlihat bahwa pola pemilih bergerak menuju arah rasional, namun tidak halnya dengan runtuhnya dinasti kekuasaan di Kutai Kartanegara. Berkuasanya dinasti kekuasaan di Kutai Kartanegara pasca Reformasi yang dipimpin oleh Syaukani hingga dilanjutkan oleh anaknya Rita berdampak pada kemajuan di kabupaten ini, terutama di kecamatan Tenggarong sebagai pusat kabupaten Kutai Kartanegara. Namun, ketika masyarakat kehilangan sosok Rita, maka pola pemiih yang dulunya rasional kembali primordialisme yang melihat identitas sebagai basis memilih.

Kalimantan Timur adalah masyarakat multietnis, baik etnis asli maupun etnis lain sebagai pendatang. Begitu juga di kabupaten Kutai Kartanegara. Etnis asli di Kutai Kartanegara adalah adalah Kutai Biru atau Kutai Keraton yang merupakan masyarakat dari kalangan bangsawan, Kutai Pesisir atau Kutai Pantai, dan Kutai Ulu atau Kutai Pedalaman yang terdiri dari Suku Dayak (Dayak Tunjung, Benuaq, Kenyah, Punan, Modang, dan Basap). Sedangkan Jawa, Bugis, dan Makassar (Sulawesi Selatan) dan Banjar (Kalimantan Selatan), Sunda (Jawa barat), Bali, dan beberapa suku dari Pulau Sumatera adalah etnis pendatang ke provinsi ini yang berbaur dengan Kutai Pesisir (Dinas Pariwisata, 2017). Namun demikian, penyebaran suku di Kutai Kartanegara tidak merata. Masyarakat dari etnis Dayak lebih banyak bermukim di kecamatan Tabang, Bugis di wilayah pesisir. Etnis Jawa dan Banjar tersebar dari wilayah tengah hingga pesisir. Keberadaan suku Jawa yang tersebar di seluruh wilayah Kutai Kartanegara yang disebabkan oleh program transmigrasi yang dilakukan pemerintah. 
Selain beragamnya etnis di Kutai Kartanegara, agama juga beragam di wilayah ini, seperti Kristen, Khatolik, Hindu, Budha, dan Islam. Namun, Islam menjadi agama mayoritas masyarakat.

Bergeraknya perilaku memilih masyarakat dari primordial menuju rasional di level nasional tidak begitu halnya perilaku memilih masyarakat di level lokal. Khususnya di Kutai Kartanegara, terlihat bahwa pasca gagalnya Rita Widyasari melaju di pemilihan gubernur di Kalimantan Timur membuat perilaku memilih masyarakat berdasarkan pada etnis. Kabupaten Kutai Kartanegara merupakan daerah yang terdiri dari beberapa etnis. Di antaranya adalah suku Kutai dan Dayak menjadi suku asli daerah ini ditambah kepada etnis pendatang yang berasal dari luar pulau Kalimantan, seperti suku Bangsa Jawa dan suku Bugis dari Sulawesi Selatan.

Jika dihubungkan dengan geopolitik yang di dalamnya banyak membahas konsep analisis yang berkaitan dengan etnografi dalam sebuah wilayah. Peta etnografi tersebut dapat berupa bahasa, daerah, budaya, etnis, dan agama sebagai relevansi politik. Secara geopolitik, Kutai Kartanegara dapat dibagi ke dalam tiga wilayah, yaitu hulu, hilir/ tengah, dan pesisir. Pembagian daerah ini berdasarkan pada kebiasaan masyarakat yang menjadikan sungai Mahakam sebagai patokannya. Semakin ke hulu sungai, maka wilayah tersebut disebut dengan wilayah hulu dan semakin ke hilir sungai, daerah tersebut dikenal dengan wilayah hilir. Sedangkan wilayah pesisir adalah wilayah yang tidak dilalui oleh sungai Mahakam tetapi berada di wilayah selat Karimata.

Daerah paling hulu di Kutai Kartanegara adalah kecamatan Tabang. Di kecamatan ini, masyarakatnya didominasi oleh suku Dayak. Semakin ke hilir maka populasi masyarakat dihuni oleh mayoritas suku Kutai, seperti di kecamatan Kembang Janggut, Kenohan, Kota Bangun, Muara Kaman, Muara Muntai, Muara Wis, Sebulu, Loa Janan, Loa Kulu danTenggarong. Sedangkan di wilayah pesisir seperti Marang 
Kayu, Muara Badak, dan Muara Jawa banyak dihuni oleh masyarakat pendatang dari Sulawesi, khususnya suku Bugis. Sedangkan wilayah lainnya merupakan daerah yang didiami oleh campuran suku asli hingga suku Jawa yang karena program transmigrasi dari pemerintah. Berdasarkan agama, beberapa suku ini dapat dipetakan. Suku Dayak penganut beragama Kristen atau aliran kepercayaan sedangkan suku Kutai dan Bugis merupakan penganut agama Islam.

Di kecamatan Tenggarong yang merupakan massa terbesar dalam pemilihan gubernur di Kutai Kartanegara dimenangi oleh pasangan nomor urut 3, Isran Noor dan Hadi Mulyadi. Kemenangan pasangan di wilayah ini dapat dilihat sebagai pasangan yang pas. Isran Noor merupakan etnis suku Kutai dan Bugis (bukan bangsawan) dan Hadi Mulyadi merupakan beretnis Banjar. Isran Noor yang dirasa lebih kompeten ketimbang Awang Ferdian Hidayat yang merupakan Kutai bangsawan yang dapat dilihat dari gelar "Awang" yang melekat di namanya. Dipilihnya pasangan Isran Noor dan Hadi Mulyadi oleh masyarakat di kecamatan Tenggarong karena rasa primordialisme masyarakat yang masih tinggi. Mereka berkeyakinan bahwa pemimpin yang berasal dari suku yang sama dirasa mampu mengenali karakter masyarakat yang memilihnya. Sehingga nantinya, komunikasi yang baik akan dengan mudah terjadi antara pemimpin dengan masyarakat. Selain itu, harapan mereka yang memilih juga tertuju pada pandangan bahwa pembangunan akan menjadi prioritas mereka yang sesama etnis. Ini tidak berarti terjadi tumpang tindih pembangunan yang ada di wilayah ini. Tetapi, mereka percaya prioritas akan tertuju kepada mereka. Sama halnya dengan kecamatan Tenggarong, beberapa kecamatan di hilir sungai Mahakam yang mayoritas didiami oleh suku Kutai seperti Muara Muntai, Kota Bangun, Muara Wis, dan Muara

6 Awang adalah gelar yang dahulunya diberikan oleh raja di Kutai kepada orang dari kalangan menengah yang bukan keturunan raja. Pemberian gelar oleh raja ini dikarenakan kemampuan dalam mengelola pemerintahan. Gelar ini kemudian diwariskan kepada keturunan masyarakat yang dahulunya mendapat gelar tersebut. 
Kaman lebih menyukai pemimpin yang berasal dari suku yang sama dengan mereka.

"Kalau soal suku, lebih baik dipimpin oleh sesama orang

Kutai juga."

(Wawancara dengan Syaiful, warga Muara Kaman, 07

Oktober 2018)

Kemenangan Isran Noor dan Hadi Mulyadi di kecamatan Tenggarong dan kecamatan lainnya tidak hanya disebabkan oleh keterwakilan etnis Kutai pada diri pasangan nomor 3 ini. Tetapi, Hadi Mulyadi sangat lebih berpengaruh dalam proses kemenangan ini bagi masyarakat. Mengingat kembali bahwa kereligiusan Hadi Mulyadi dirasa cocok dijadikan pemimpin oleh masyarakat Tenggarong. Suku Kutai dan Banjar pendatang dari Kalimantan Selatan merupakan penganut agama Islam yang taat. Hubungan ajaran agama Islam dan perilaku memilih terhadap pemimpin sangat mendominasi perilaku mereka dalam memilih.

Kecamatan Tabang yang merupakan kecamatan terjauh dari ibu kota kabupaten Kutai Kartanegara, menjadi wilayah yang dihuni oleh mayoritas suku bangsa Dayak. Satu-satunya calon gubernur yang beretnis Dayak adalah Syaharie Ja'ang. Tidak bisa dielakkan lagi bahwa kemenangan pasangan Syaharie Ja'ang dan Awang Ferdian Hidayat sangat besar di kecamatan Tabang. Jika melihat hasil di tingkat provinsi, maka pola yang sama dengan keadaan di Kutai Kartanegara juga demikian. Kabupaten Kutai Barat dan Mahakam Hulu menjadi dua kabupaten terbesar dalam penyumbangan suara bagi pasangan nomor urut 2 ini. Sebab, dua kabupaten ini menjadi tempat bermukimnya mayoritas etnis Dayak. Falsafah etnis Dayak "menjadi tuan rumah di negeri sendiri" adalah bersatunya masyarakat Dayak untuk memilih Syaharie Ja'ang.

Pengalaman Syaharie Jảang sebagai ketua Persatuan Dayak 
Kalimantan Timur (PDKT) membuat Ja’ang cukup populer di kalangan etnis ini. Dalam salah satu sambutannya di Musyawarah Cabang PDKT, Ja'ang menyampaikan bahwa orang Dayak tidak hanya menjadi penonton dalam perpolitikan di Kalimantan Timur tetapi harus ikut berpartisipasi dalam politik. Suara bulat juga diberikan oleh PDKT ini kepada Syaharie Ja'ang yang menilai bahwa Syaharie Ja’ang mampu menyatukan dan membangkitkan etnis Dayak untuk lebih berani. Keberpihakan etnis Dayak pada Syaharie Ja'ang tidak hanya pada saat memilih dalam pemilihan gubernur di Kalimantan Timur. Tetapi, jauh sebelum pemilihan gubernur ketika Syaharie Ja'ang diperiksa oleh institusi Polisi Republik Indonesia (POLRI) di Jakarta. Masyarakat Dayak dalam Forum Dayak Bersatu (FDB) datang ke Jakarta untuk melakukan pembelaan kepada Syaharie Jảang. Dari keadaan ini terlihat bahwa Syaharie Ja'ang menjadi tokoh sentral bagi etnis Dayak di Kalimantan Timur. Sama halnya dengan masyarakat di kecamatan Tenggarong, masyarakat di kecamatan Tabang juga melihat bahwa Syaharie Ja’ang adalah sosok yang lebih baik menjadi pemimpin.

Kecamatan Marang Kayu, Muara Badak, dan Muara Jawa menjadi rumah bagi kemenangan Andi Sofyan Hasdam-Rizal Effendi. Wawancara yang dilakukan di Muara Badak membuktikan bahwa adanya nama "Andi" di bagian nama calon gubernur nomor 1 ini mampu menjadi penguat basis identitas kesukuan masyarakat dalam memilih, khususnya keturunan dari Sulawesi Selatan. Meskipun masyarakat tidak mengetahui dan juga tidak memperhatikan program dan visi misi pasangan ini, namun kuatnya rasa persaudaraan membuat Andi Sofyan Hasdam berhasil membuat masyarakat asal Sulawesi Selatan memilihnya. 
"Saya kemarin memilih yang ada nama Andi di depannya. Saya pilih dia karena sesama orang Bugis. Saya memang tidak mengenalnya. Tetapi sesama Bugis, kita bersaudara, maka saya memilih dia."

(Wawancara dengan warga di Muara Badak, 05 Oktober 2018)

Andi Sofyan Hasdam yang juga merupakan ketua Kerukunan Keluarga Sulawesi Selatan (KKSS) Kalimantan Timur menjadi sosok pemersatu bagi masyarakat Kutai Kartanegara keturunan dari Sulawesi Selatan di wilayah ini. Khususnya, di wilayah pesisir yang memang banyak dihuni oleh masyarakat beretnis Bugis. Dengan demikian, posisi geopolitik di pesisir dikuasai oleh pasangan Andi Sofyan Hasdam-Rizal Effendi.

Lain halnya pasangan Rusmadi Wongso-Safaruddin yang juga menang di tiga wilayah, yaitu Tenggarong Seberang, Samboja, dan Anggana. Kehadiran etnis Jawa yang besar dan menjadi etnis terbesar di Kalimantan Timur dan di Kutai Kartanegara membuat keberuntungan bagi Rusmadi Wongso yang berlatar belakang etnis Jawa. Masyarakat yang berada di wilayah transmigran di Anggana lebih cenderung memilih Rusmadi Wongso ketimbang masyarakat etnis Jawa yang bukan di wilayah transmigran. Selain kuatnya etnis Jawa dalam memilih Rusmadi Wongso, tidak bisa diabaikan bahwa Rusmadi berpengalaman di pemerintah sebagai sekretaris daerah. Selain itu, hal yang membuat menangnya Rusmadi Wongso-Safaruddin di tiga kecamatan ini adalah sosok Safaruddin. Ikutnya Safaruddin dalam bursa gubernur Kalimantan Timur telah menjadi perhatian masyarakat Kutai Kartanegara. Safaruddin mulai gencar mempromosikan dirinya jauh hari sebelum adanya penetapan calon gubernur dan wakil gubernur Kalimantan Timur, bahkan saat dia masih menjabat sebagai Kepala Polisi Daerah (Kapolda) Kalimantan Timur. Promosi gencar 
dilakukan oleh Safaruddin, baik di jalan-jalan provinsi maupun jalanjalan desa, terutama melalui baliho yang terpampang cukup banyak. Dengan banyaknya baliho tersebut, membuat Safaruddin dikenal dengan julukan "Raja Baliho". Masyarakat mencari informasi mengenai Safaruddin dengan menjamurnya baliho tersebut. Selain sebagai Kapolda Kalimantan Timur, Safaruddin juga kandidat keturunan dari Sulawesi Selatan.

\section{Kesimpulan}

Dari narasi di atas, perilaku memilih masyarakat pasca runtuhnya dinasti kekuasaan Syaukani-Rita di Kutai Kartanegara adalah kembalinya pola perilaku memilih masyarakat di tingkat lokal menjadi primordial. Pola primordial tersebut berbasis pada identitas, baik identitas berdasarkan etnis maupun agama dalam memilih gubernur dan wakil gubernur Kalimantan Timur 2018. Selain itu, terlihat bahwa kondisi geopolitik juga memengaruhi kemenangan suatu kandidat di kabupaten Kutai Kartanegara. Pola primordial ini bukanlah pola yang bertahan dari dulunya. Di tahun 2015 dalam pemilihan bupati di Kutai Kartanegara, masyarakat cenderung memilih pola rasional. Pemilih menjadi rasional ini dikarenakan oleh dinasti Syaukani-Rita telah mampu melakukan pembangunan, baik fisik maupun non fisik, yang menurut masyarakat telah mampu membuat Kutai Kartanegara semakin baik. Namun, ketika Rita gagal dalam mengikuti kontestasi pemilihan gubernur Kalimantan Timur, masyarakat kehilangan tokoh yang diyakini cakap untuk membawa Kalimantan Timur lebih baik. Karena kehilangan sosok tersebut, menjadikan pemilih di Kutai Kartanegara di tahun 2015 yang rasional dalam memilih bupati Kutai Kartanegara kembali pada pola primordial.

Melihat perilaku memilih masyarakat Kutai Kartanegara berdasarkan etnis, tampaklah masyarakat Dayak cenderung memilih Dayak, yaitu Syaharie Ja'ang yang berpasangan dengan Awang Ferdian 
Hidayat. Masyarakat yang beretnis Kutai dan Banjar cenderung memilih pemimpin yang sama dengan mereka, yaitu Isran Noor dan Hadi Mulyadi. Sedangkan untuk masyarakat Jawa dan Bugis cenderung memilih Andi Sofyan Hasdam-Rizal Effendi dan Rusmadi Wongso-Safaruddin. Sedangkan masyarakat yang menganut agama Islam cenderung memilih Isran Noor dan Hadi Mulyadi yang melihat kepada Hadi Mulyadi sebagai wakil gubernur ketimbang Isran Noor sebagai gubernur.

Selain itu, pemilih tersebut dibagi dalam tiga wilayah di Kutai Kartanegara, wilayah hulu, hilir/tengah, dan pesisir. Wilayah hulu yang didominasi oleh etnis Dayak, yaitu kecamatan Tabang menjadikan Syaharie Ja'ang-Awang Ferdian Hidayat sebagai calon gubernur dan wakil gubernur yang pantas memimpin Kalimantan Timur. Sedangkan wilayah tengah yang mayoritas dihuni oleh etnis Kutai dan Banjar cenderung memilih Isran Noor dan Hadi Mulyadi. Pemilih dalam memilih pasangan nomor 3 ini tidak hanya melihat pada identitas etnis mereka, tetapi juga sosok Hadi Mulyadi yang terlihat lebih religius. Karenanya, pasangan ini diuntungkan dari etnis Kutai dan kuatnya penganut agama Islam sehingga membuat Isran Noor dan Hadi Mulyadi menang di 11 kecamatan di Kutai Kartanegara. Kemenangan yang besar ini menjadikan mereka pemenang di kabupaten Kutai Kartanegara. Sedangkan wilayah pesisir melihat pola yang hampir sama dengan wilayah hulu dan hilir. Hadirnya komunitas masyarakat etnis Bugis dan Jawa membuat masyarakat lebih memilih Andi Sofyan Hasdam-Rizal Effendi atau Rusmadi-Safaruddin.

Kuatnya primordialisme di Kutai Kartanegara disebabkan begitu beragam etnis yang mendiami kabupaten ini. Selain itu, calon gubernur secara tidak langsung mengarahkan pada hal yang mampu mendulang suara, seperti Kalimantan Timur dipimpin oleh orang asli Kalimantan Timur. Perilaku memilih masyarakat berdasarkan identitas ini diyakini adanya rasa percaya masyarakat dengan sesama identitasnya. Rasa 
diprioritaskan, persaudaraan yang tinggi, dan keyakinan sesama etnis asli yang paham dengan kondisi daerah Kalimantan Timur.

\section{Referensi}

Agustino, Ldan Yusoff. (2009). Pemilihan Umum dan Perilaku Pemilih: Analisis Pemilihan Presiden 2009 di Indonesia. Jurnal Poelitik, 5 (1), 415-443.

Ananta, A., E. N. Arifin, \& L. Suryadinata. (2004). Indonesian Electoral Behaviour: A Statistical Perspective. Singapore: ISEAS.

Bartels, L. M. (2012). The Study of Electoral Behavior. Dalam J. E. Leighley (ed), The Oxford Handbook of American Elections and Political Behavior (pp. 240). Oxford: Oxford University Press

Baswedan. (2004). Sirkulasi Suara Dalam Pemilu 2004. CSIS, 33 (2), 173-189.

Dinas Pariwisata (2018, Oktober 29). Gambaran Umum Kabupaten Kutai Kartanegara. Diakses dari http://dispar.kutaikartanegarakab.go.id/ halaman/gambaran_umum_kabupa ten_kutai_kartanegara.

Efriza. (2012). Political Explore, Sebuah Kajian Ilmu Politik. Bandung: Alfabeta.

Gaffar, A. (1992). Javaners Voters, A Case Study of Election Under a Hegemonic Party System. Yogyakarta: Gadjah Mada University Press.

Geertz, C. (1960). The Religion of Java. New York: The Free Press.

Haryanto. (2014). Kebangkitan Party ID: Analisis Perilaku Memilih dalam Politik Lokal di Indonesia. Jurnal Ilmu Sosial dan Ilmu Politik, 17 (3), 291-308. 
Hartono, B. (2018, Oktober 04). Hasil Survei, Elektabilitas Rita dan Awang Ferdi Bersaing, Survei lain Belum Tentu. Diakses dari http:// kaltim.tribunnews.com/2017/08/07/ hasil-survei-elektabilitasrita-dan-awang-ferdi-bersaing-survei-lain-belum-tentu.

King, D. Y. (2003). Half-hearted Reform: Electoral Institutions and the Struggle for Democracy. Connecticut: Praeger.

KPU RI. (2017, Oktober 08). Diakses dari https://pilkada2015.kpu. go.id/kutaikartanegara kab.

Lau, R. R \& D. P. Redlawsk. (2006). How Voters Decide. New York: Cambridge University Press.

Linawati, M. (2018, Oktober 20). Hakim Nyatakan Rita Widyasari Terbukti Terima Gratifikasi Rp 110,7 Miliar. Diakses dari https:// www.liputan6.com/news/read/ 3581236/hakim-nyatakan-ritawidyasari-terbukti-terima-gratifikasi-rp-1107-miliar.

Mujani, S. dan R. Wiliam Liddle. (2006). Leadership, Party and Religion: Explaining Voting Behavior in Indonesia. Jakarta: Freedom Institute.

Mujani, S. dan R. Wiliam Liddle. (2010). Personalities, Parties, and Voters. Journal of Democracy, 21 (2), 35-49.

Mujani, S., R. W. Liddle, \& Ambarki. (2012). Kuasa Rakyat: Analisis Tentang Perilaku Memilih dalam Pemilihan Legislatif dan Presiden Indonesia Pasca Orde Baru. Jakarta: Mizan Publika.

Museum Rekor Indonesia (2018, Oktober 04). Diakses dari http:// muri.org/?s=rita+ widyasari.

Novianto, E. (2017). Analisis Perilaku Pemilih dalam Pemilihan Kepala Daerah Kabupaten Kutai Kartanegara Tahun 2015. Jurnal Ilmu Sosial Mahakam, 6 (1), 21-34. 
Pamungkas, S. (2010). Pemilu, Perilaku Pemilih \& Kepartaian. Sleman: Institute for Democracy and Welfarism.

Roth, D. (2008). Studi Pemilu Empiris: Sumber, Teori, Instrumen dan Metode. Jakarta: Friderich-Naumann-Stiftung fur die Freiheit.

Santoso, P., L. N. Bayo, Y. Lopo, \& Sudirman. (2018). Kecerdikan Rezim Lokal dalam Menyikapi Konsentrasi Uang: Transformasi Paternalisme Menjadi Oligarki. Dalam L. N. Bayo, P. Santoso, \& W. P. Samadhi. Rezim Lokal di Indonesia: Memaknai Ulang Demokrasi Kita (pp. 121-154). Jakarta: Yayasan Pustaka Obor Indonesia.

Simanjuntak, J. (2018, Oktober 20). Status Tersangka Bupati Rita Widyasari Nyaris Serupa Kasus Sang Ayah. Diakses dari http:// www.tribunnews.com/nasional/2017/09/27/ status-tersangkabupati-rita-widyasari-nyaris-serupa-kasus-sang-ayah?page $=2$.

Suara Pembaruan (2018, Oktober 04). Diakses dari http://sp.beritasatu. com/home/terus-unggul-di-survei-rita-berpotensi-jadigubernur-perempuan-pertama-di-kaltim/ 120334.

Pamungkas, A. S. \& G. Octaviani. (2017). Aksi Bela Islam dan Ruang Publik Muslim: Dari Representasi Daring ke Komunitas Luring. Jurnal Pemikiran Sosiologi, 4 (2), 65-87.

Valentina, T. R. (2009). Peluang Demokrasi dan Peta Perilaku Pemilih Terhadap Partai Politik untuk Pemilu 2009 di Yogyakarta. Jurnal Demokrasi, VIII (2), 167-186.

Yustiningrum, R. E \& W. Ichwanuddin. (2015). Partisipasi Politik Dan Perilaku Memilih Pada Pemilu 2014. Jurnal Penelitian Politi, 12 (1), 117-135. 